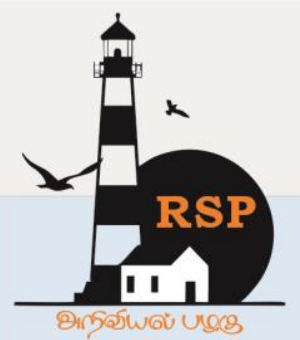

INTERNATIONAL RESEARCH JOURNAL ON

e-ISSN : 2582 - 4376 ADVANCED SCIENCE HUB Open Access

RSP SCIENCE HUB

(The Hub of Research Ideas)

Available online at www.rspsciencehub.com

\title{
Heavy Metal Analysis by Spectrophotometric Equation
}

Shaziya Mohammed Irfan Momin

Assistant Professor, Department of Chemistry, G.M.Momin Women's College, Bhiwandi, Dist Thane,

Maharashtra, India.

shaziyamomin79@gmail.com

Abstract

Textile Industry is one of the most significant and biggest industrial sectors known. In terms of environmental impact it exhibit very important role, since it consumes huge quantity of textile industrial processed water and generates vastly polluted discharge water. This industry utilizes high volume of water throughout its operation, from the washing of fibers to bleaching, mercerizing, dyeing, printing and washing of finished products and releases waste water in the nearby water reservoirs which makes the water harmful to aquatic organisms and plants. Therefore this study is carried out to find the concentration of Titanium metal in effluent water and for that the samples were collected from textile dyeing industries of Bhiwandi city, District Thane, State Maharashtra, and analysed for amount of Titanium metal present in the effluent water by spectrophotometric method and equation. The level of this metal obtained by present experimental work is less than the standard value. It was therefore concluded that textile effluents are safe with regards to Titanium metal pollution.

Keywords: Titanium, Industrial effluent, Spectrophotometric method

\section{Introduction}

Wastewaters from the factories were untreated and that high amounts of pollutants, as shown by the high values of pollution characteristics, were discharged from them daily in to the nearby water bodies. These pollutants are known to destroy micro-organisms stabilizing wastes in the receiving stream and leading to a reduction in the self - purifying capacity of the stream $(4,17)$.

Water supply systems and drinking water inaccessibility in developing countries is a global concern that calls for immediate action. About 884 million people in the world still do not get their drinking water from approved sources, and almost all of these people are in developing regions . Providing quality drinking water to all citizens who are deprived of access to water will serve as the breaking point of poverty alleviation in most developing countries. Having reliable drinking water is now recognised by United Nations as a human right. A heavy metal is any metallic element that has a relatively high density and is toxic or poisonous even at low concentrations. Heavy metals exist as natural constituents of the earth crust and are persistent environmental contaminants, because they cannot be degraded or destroyed $(5,7,13)$. Titanium has its application in several industries, used for making different alloys, there is a increase use of titanium in different field due to which it become necessary to analyse the titanium metal by simple and sensitive techniques, as several other techniques are reported by literature survey which are highly sophisticated and expensive but spectrophotometric method of analysis are quite simple,rapid, interference free and cheap technique of analysis of titanium metal $(15,16,18)$.

Heavy metals are generally bounded with inert material and concentration of these metals have 
increased many times because of manmade activities. Human exposure to harmful heavy metals can occur in many ways, ranging from the consumption of contaminated food, exposure to air-borne particles, and contact or consumption of contaminated water and accumulate over a period of time. Water related diseases can often be attributed to exposure to elevated heavy metal concentrations of both organic and inorganic contaminants. Many of these compounds exist naturally, but their concentration has increased as a result of anthropogenic activities $(5,14)$.

Large quantity of water is used for various dyeing and finishing processes in the textile industry. In turn this industry releases huge quantity of waste water with elevated level of organic matter which undergo biodegradation slowly with great difficulty and which has importunate color which is resistant to light, temperature, detergents or microbial attack. The textile dyeing industry has always sought systems that provide maximum efficiency. It is known that these industries have used over 100,000 different dyes with a production of 700,000 tons per year. Up to $15 \%$ of this is discharged as waste water. Therefore, it can be estimated that around 50,000 tons of dyes are discharged as waste water annually due mainly to ineffective processes of dyeing or dyes with low affinity with fibers. Cotton is the substrate that requires the most water in this process. The cotton dyeing industry mainly uses reactive dye reagents. These dyes represent approximately $20-30 \%$ of the total consumption of dyes $(310,11)$.

\section{Material \& Method:}

The effluent collected from three different industries of Bhiwandi city located in District Thane, State Maharashtra. Sampling done in the afternoon from $12.30 \mathrm{pm}$ to $1.30 \mathrm{pm}$ and effluents were collected in a plastic containers of one liter capacity after washing with $1 \%$ nitric acid, rinsing with double distilled water. The samples were preserved under refrigeration till complete analysis. It is necessary to save the sample from alteration in composition and deterioration due to several interactions. All the reagents used for the analysis were AR grade and double distilled water was used for preparation of solutions $(1,2)$. Titanium metal form complexes with hydrogen peroxide in acidic medium having maximum absorption at $410 \mathrm{~nm}$ and $460 \mathrm{~nm}$. Absorbance of series of standard solution of Titanium metal is measured at both the wavelength along with absorbance measurement of effluent water.

\subsection{Statistical Analysis:}

Data produced in present work were evaluated using Microsoft excel spreadsheet. Measured values of heavy metals were analyzed using MS excel software to create means,median,mode,maximum value, minimum value,error,average deviation, standard deviation and variance. The data are represented as mean \pm standard deviation. Differences in concentration levels obtained for a given parameter along sampling sites were evaluated in terms of error.

\section{Result and Discussion:}

Table.1. Determination of Titanium

\begin{tabular}{|c|c|c|c|c|c|}
\hline \multirow{2}{*}{$\begin{array}{c}\text { Titanium metal in } \\
\text { ppm }\end{array}$} & $\begin{array}{c}\text { Amount of } \\
\text { sulphuric } \\
\text { acid } \\
\text { in }\left(\mathrm{cm}^{3}\right)\end{array}$ & $\begin{array}{c}\text { Amount of } \\
\text { hydrogen } \\
\text { peroxide in } \\
\left(\mathrm{cm}^{3}\right)\end{array}$ & $\begin{array}{c}\text { Total } \\
\text { dilution(c } \\
\left.\mathrm{m}^{3}\right)\end{array}$ & \multicolumn{2}{|c|}{ Absorbance at } \\
\cline { 5 - 7 } & 25.0 & 3.0 & 100 & 0.043 & 0.037 \\
\hline 2.0 & 25.0 & 3.0 & 100 & 0.048 & 0.041 \\
\hline 3.0 & 25.0 & 3.0 & 100 & 0.054 & 0.046 \\
\hline 4.0 & & & & & \\
\hline
\end{tabular}


Table.2. Statistical Analysis:

Calculation of mode is NA in all effluent water samples. Table 2.1 Dyeing Effluent-I

\begin{tabular}{|c|c|c|c|c|}
\hline $\begin{array}{c}\text { Amount } \\
\text { of Ti in } \\
\mathrm{mg}\end{array}$ & Mean & Median & Max & Min \\
\cline { 1 - 1 } 3.4906 & \multirow{2}{*}{3.4793} & 3.4864 & 3.4906 & 3.4609 \\
\cline { 1 - 2 } 3.4864 & & & & \\
\hline 3.4609 & & & & \\
\hline
\end{tabular}

Table 2.3 Dyeing Effluent-I

\begin{tabular}{|l|l|l|l|}
\hline Error & SD & $\begin{array}{l}\text { Avg. } \\
\text { Deviation }\end{array}$ & Variance \\
\hline $1.90 \mathrm{E}-07$ & 0.016 & 0.0122 & 0.0002 \\
& & & \\
\hline
\end{tabular}

Table 2.5 Dyeing Effluent-II

\begin{tabular}{|c|c|c|c|c|}
\hline $\begin{array}{c}\text { Amount } \\
\text { of Ti in } \\
\mathrm{mg}\end{array}$ & Mean & Median & Max & Min \\
\cline { 1 - 2 } 3.5964 & \multirow{2}{*}{3.544} & 3.532 & 3.596 & 3.502 \\
\cline { 1 - 2 } 3.5327 & & & & \\
\cline { 1 - 2 } 3.5029 & & & & \\
\hline
\end{tabular}

Table 2.2 Dyeing Effluent-II

\begin{tabular}{|c|c|c|l|}
\hline Error & SD & $\begin{array}{c}\text { Avg. } \\
\text { Deviation }\end{array}$ & Variance \\
\hline $\begin{array}{c}3.62 \mathrm{E}- \\
07\end{array}$ & 0.047763 & 0.0349333 & 0.002281 \\
\hline
\end{tabular}

Table 2.4 Dyeing Effluent-III

\begin{tabular}{|l|l|l|l|l|}
\hline $\begin{array}{l}\text { Amount } \\
\text { of Ti in } \\
\mathrm{mg}\end{array}$ & Mean & Median & Max & Min \\
\cline { 1 - 1 } 3.5159 & 3.473433 & 3.4522 & 3.5159 & 3.4522 \\
\cline { 1 - 2 } 3.4522 & & & & \\
\cline { 1 - 2 } 3.4522 & & & & \\
\hline
\end{tabular}

Table 2.6 Dyeing Effluent-III

\begin{tabular}{|l|l|l|l|}
\hline Error & SD & $\begin{array}{l}\text { Avg. } \\
\text { Deviation }\end{array}$ & Variance \\
\hline $3.8 \mathrm{E}-07$ & 0.03 & 0.0283 & 0.001 \\
& & & \\
\hline
\end{tabular}




\section{Textile Effluent Water}

\begin{tabular}{|l|l|l|}
\hline Sr. & Sample & $\begin{array}{l}\text { Amount of Titanium in } \\
\mathrm{mg} \text { with standard } \\
\text { Noviation value }\end{array}$ \\
\hline 1 & Effluent-I & $3.479 \pm 0.016073$ \\
\hline 2 & Effluent-II & $3.544 \pm 0.047763$ \\
\hline 3 & Effluent-III & $3.473 \pm 0.036777$ \\
\hline
\end{tabular}

Amount of Titanium in $\mathrm{mg}$

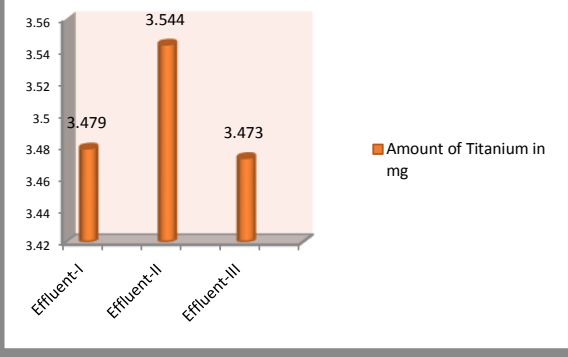

Fig.1.Amount of Titanium

Table.4.Adopted from World Health Organization (WHO) and Nigerian Standard for Drinking Water Quality (NSDQW) water quality guidelines (6)

\begin{tabular}{|l|l|l|l|l|l|}
\hline \multirow{2}{*}{ Standard body } & \multicolumn{2}{|l|}{$\begin{array}{l}\text { Acceptable limit for } \\
\text { drinking water }\end{array}$} & $\begin{array}{l}\text { Acceptable limit for discharge } \\
\text { into stream }\end{array}$ & $\begin{array}{l}\text { Obtained } \\
\text { value }\end{array}$ \\
& $\begin{array}{l}\text { NSDQW } \\
\text { standard } \\
\text { ppm }\end{array}$ & WHO & NSDQW & WHO \\
standard ppm & $\begin{array}{l}\text { standard } \\
\text { ppm }\end{array}$ & standard ppm & \\
\hline Titanium & Not & Not specified & Below 10 & Not specified & $3.473 \mathrm{mg}$ to \\
& specified & & & & $3.544 \mathrm{mg}$ \\
\hline
\end{tabular}

Obtained value from present experiments $(3.473 \mathrm{mg}$ to $3.544 \mathrm{mg}$ ) are less than the NSDQW standard (Below 10ppm for discharge into stream)for titanium metal.

Table.5. FAO guidelines for metal (8)

FAO guidelines for trace metals in irrigation water: Recommended maximum concentration (mg/L)

\begin{tabular}{|l|l|l|}
\hline Parameter & $\begin{array}{l}\text { Recommended maximum concentration } \\
(\mathrm{mg} / \mathrm{L})\end{array}$ & Remark \\
\hline $\mathrm{Ti}$ & ----- & $\begin{array}{l}\text { Effectively excluded by plants; } \\
\text { specific tolerance unknown }\end{array}$ \\
\hline
\end{tabular}

A study of hygienic standard for titanium in the source of drinking water: Chronic toxicity test of titanium in rats showed that the maximum noneffective concentration was $1.08 \mathrm{mg} / \mathrm{L}$. It is suggested that the maximum allowable concentration of titanium in drinking water may be $0.1 \mathrm{mg} / \mathrm{L}(12)$.

Assessment of toxicity of titanium indicates that acute toxicity through oral path was of low order of magnitude as per toxicity classification.
Titanium has shown no evident collective outcome, nor was there mutagenesis confirmable (12).

\section{Conclusion:}

The textile industry is one of the larger consumers of potable water and, consequently, produces a huge amount of wastewater. Although the typical characteristics of textile factory wastewaters have 
been previously studied, most of the standard bodies are not provided with any specific value of amount of titanium for discharge in to the public water. The amount of metal under study are less than the NSDQW standard, therefore the textile dyeing effluent water is safe with respect to concentration of titanium metal. Different Processes that takes place in textile industries are sizing, de-sizing, scouring, bleaching, mercerizing, dyeing, printing, finishing .These all steps are responsible for generation of following as a waste and contaminants: biochemical oxygen demand from sizes, enzymes, waxes, starch, sodium hydroxide, pectins, fats, oils, soap, surfactant, sizes, sodium silicate, hydrogen peroxide, alkaline conditions, organic stabilizer, salt, metal, surfactant, acidic condition, colour, formaldehyde, solvents, urea, softeners and users(8).

The large volumes of wastewater generated also contain a wide variety of chemicals used throughout processing. These can cause damage if not properly treated before discharge to the environment. The aquatic toxicity of textile industry wastewater varies considerably among production facilities. The sources of aquatic toxicity can include salt, surfactants, ionic metals and their metal complexes, toxic organic chemicals, biocides and toxic anionic substances. Most textile dyes have low aquatic toxicity. Wastewater in bleaching, mercerizing, dying, printing and finishing sectors required separate treatment which can decrease the concentration of polluting agents (3).

Always there is a need to develop simple, costeffective and eco-friendly treatment systems for the remediation of textile effluents to minimize water pollution for sustainable environmental and economic development(9).

Several studies clearly indicates that surface water/groundwater are getting contaminated slowly due to rapid industrialization. Therefore, it is necessary to enforce water quality regulations for industries setting up effluent treatment plants. Proper treatment of textile industry effluents is needed before their safe disposal into water bodies. Industries should be set up with their independent effluent treatment plants and should remain effectively operational in order to safeguard the quality of water for future generations. Separate drainage system must be constructed to prevent direct discharge of industrial effluents into water bodies. The disposal sites for industrial and urban wastes should be away from the residential areas in the city. Strict implementation of environmental regulations is necessary. As the level of Titanium metal is below standard limit therefore Textile dyeing industrial water from Bhiwandi city are safe with respect to toxicity of titanium metal ion.

\section{References:}

[1] The Environment (Protection) Rules, 1986, Published Vide S.O. 844(E), Dated 19.11.1986 Published In The Gazette Of India, Ext., Part 2., Section 3(I), Dated 19.11.1986

http://www.bareactslive.com/ACA/ACT52 8.HTM

[2] Yaseen, D.A., Scholz, M. (2019).Textile Dye Wastewater Characteristics and Constituents of Synthetic Effluents: A Critical Review. Int. J. Environ. Sci. Technol. 16, 1193-1226. https://doi.org/10.1007/s13762-018-2130-z

[3] Imtiazuddin S.M., Mumtaz M. , Khalil A. M.(2012).Pollutants Of Wastewater Characteristics In Textile Industries, Journal Of Basic \& Applied Sciences,8, 554-556.

[4] AdemorotiC. M. A. , OmodeA. A. (1992). Studies Of Textile Effluent Discharges In Nigeria, International Journal Of Environmental Studies,39(4). https://doi.org/10.1080/0020723920871070 4

[5] Samuel J. Cobbina, Abudu B. Duwiejuah, Reginald Q., Samuel O., Noel B. (2015).Comparative Assessment of Heavy Metals in Drinking Water Sources in Two Small-Scale Mining Communities in Northern Ghana,Int J Environ Res Public Health, 12(9), 10620-10634.

DOI: 10.3390/ijerph120910620

[6] Shehu J., Obadaki Y.Y., Koki I.B. (2016). International Journal Of Chemical, Material And Environmental Research, 3 (1), 1-7. www.Ijcmer.Org

[7] General Standards for Discharge of Environmental Pollutants https://tspcb.cgg.gov.in/Environment/Gene 
ral $\% 20$ Standards $\% 20$ For $\% 20$ Discharge $\% 2$ 0Of\%20Environmental\%20Pollutants.pdf

[8] A Compendium Of Standards For Wastewater Reuse In The Eastern Mediterranean Region, World Health Organization Regional Office For The Eastern Mediterranean Regional Centre For Environmental Health Activities CEHA, 2006, WHO-EM/CEH/142/E

https://apps.who.int/iris/bitstream/handle/1 0665/116515/dsa1184.pdf; sequence=1

[9] Bhatia D., Sharma N R, Kanwar R., Singh J , (2018). Physicochemical Assessment of Industrial Textile Effluents of Punjab (India), Applied Water Science 8:83 https://doi.org/10.1007/s13201-018-0728-4 [10] Orts F, Rio A.I.D, Molina J., Bonastre J., Cases F. , (2019). Study Of The Reuse Of Industrial Wastewater After Electrochemical Treatment Of Textile Effluents Without External Addition Of Chloride , Int. J. Electrochem. Sci., 14 1733 - 1750, doi: 10.20964/2019.02.27

International Journal of Electrochemical Science www.electrochemsci.org

[11] Ghaly AE, Ananthashankar R, Alhattab M, Ramakrishnan V.V.,(2014). Production, Characterization and Treatment of Textile Effluents: A Critical Review. J Chem Eng Process Technol 5: 182. doi: 10.4172/2157-7048.1000182

[12] Zhonghua Y., Fang Y., XueZ.Z. , (1993). A Study of Hygienic Standard For Titanium In The Source Of Drinking Water, 27(1), 26-8.

www.ncbi.nlm.nih.gov > pubmed

[13] Linnik P. N., Zhezherya V. A. (2015), Titanium in Natural Surface Waters: The Content and Coexisting Forms, Russian Journal of General Chemistry, 24(1), 41-55.

[14] Kant R. (2012).Textile dyeing industry an environmental hazard. Natural Science,4(1), 22-26.

[15] Liping S., Keyue W., Yan L., Qiyuan F., Wei Z., and Hong L., (2017). Vanadium Exposure-Induced Striatal Learning And Memory Alterations In Rats, 62, 124-129. doi:10.1016/j.neuro.2017.06.008.,

[16] Tibau A.V., Grube B.D., Velez B.J.,
Vega V.M., Mutter J. (2019). Titanium Exposure and Human Health. Oral Sci Int., 00:1-10. https://doi.org/10.1002/osi2.1001

[17] Sorsa S., Chibssa Y., Tilahun G. and Fitamo D. (2014). Heavy Metal Concentrations and Physicochemical Characteristics of Effluent along the Discharge Route from Hawassa Textile Factory. Ethiopia,J Environ Anal Toxicol,5(4), 285 .

[18] Srilalitha V., Aluru R.G.P., Kumar K.R., Seshagiri V., Rao L. K., Rao R., (2010), A New Spectrophotometric Method For The Determination Of Trace Amount of Titanium(IV),Series Physics,Chemistry And Technologies,8(1),15-24. DOI:10.2298/FUPCT1001015S 